\title{
Observations on Change
}

\section{Vernon D Miller*}

Departments of Communication and Management, Michigan State University, USA

Observations by outsiders can be informative, provocative, and sometimes even helpful. I write this essay as an outsider observer to Mass Communication and Journalism from the relative safety of my Organizational Communication academic enclave and ask how you are reacting to three readily apparent (from my vantage point) crises.

What are the three crises? First, the Mass Communication and Journalism fields are losing full-time paid positions hand over fist. For instance, the decline of traditional revenue sources is leading to staff reductions in newsrooms, budgets are ever tighter, and lower salaries will prevail in the future. In corporation's worldwide, engineers as well as accountants, web designers, and human resource professionals with internet savvy are taking over Information Officer, Communication Specialist, and Public Relations positions. Second, the future of much of the world's news information will be generated by those untrained in your fields. Across the globe, individuals with elementary web skills are creating news blogs that are followed (and at times believed) by thousands. Social media sites have become effective tools for disseminating news and harnessing the energy of political movements. I personally worry that Internet, television, and written news media worldwide will lose the hard fought advantages of professional, objective as possible and ethical practices in information gathering and dissemination. Third, you are training students in undergraduate and graduate courses for many jobs that will not exist the way they have in the $19^{\text {th }}$ and $20^{\text {th }}$ centuries. Deans and academic governing bodies look unkindly at majors and programs where the professions appear to be shrinking.

Simply put, will universities need departments of Mass Communication or Journalism in the future? The techies and web design folks assigned to Engineering and Art departments, respectively, and the revered ideologies and skills related to news development and reporting can be farmed out to Philosophy and English where argumentation, debate, and analytical thinking flourish. However, I would argue that the world needs your academic fields now more than ever, but with an important modification to your mission.

From an organizational communication perspective, the strength of your fields is not about teaching theories and skills, but in the epistemic lifestyle of discovering and sharing truths responsibly. I suggest that you evaluate and revise these fields' vocational socialization messages.
Vocational socialization broadly refers to messages from family members, educational experiences, peers, media, and part-time work that shape individuals' beliefs regarding the nature of work, appropriate vocations to pursue, and how to communicate with others at work. The internalization of these messages forms the basis (though incomplete and at times misguided) of job and occupational expectations. One application of vocational socialization examines what influenced you, your peers, and your students to select your chosen profession (i.e., how did you decide what you wanted to be/do when you grew up?).

Another, more important application of vocational socialization in this context examines the values communicated about what it means to study and be a Mass Communication and Journalism professional. Instructors must go beyond the skills, knowledge, and abilities embedded in instructional materials to identify the implicit and explicit values (and their importance) that they wish to convey to others about media professionalism in the $21^{\text {st }}$ Century. Educational institutions have always socialized youth into society, introduced and reinforced vocational standards, codes, and interaction norms, and provided feedback on individual intellectual, physical, and social abilities. Your challenge is communicating the values inherent in questions, such as, what does it mean to be a media content-producer? What ethical practices and information gathering and information sharing standards should guide us all when we take to the Internet? How should training in Mass Communication and Journalism influence your lifestyle and actions in your community?

With answers to these questions, your next challenge is to communicate to budding bloggers, Twitter-ers, would-be journalists, and media creators worldwide, young and old, what are the best information gathering and dissemination practices for news reporting, the standards by which to judge official and unofficial news sites on any continent, and the distinguishing characteristics of individuals devoted to Mass Media and Journalism fields whether they are professionally trained or an amateur. Pardon my naiveté, but I would hope that these standards would be promoted as broadly and ardently as information on balanced diet or safe sex are. Your field has a rich legacy and great potential to bring good by which all societies can prosper. It's time to examine your vocational values and how you are disseminating your messages to all.

*Corresponding author: Vernon D Miller, Departments of Communication and Management, Michigan State University, USA, Tel :( 517) 355-3280; Fax: (517) 432 1192; E-mail: vmiller@msu.edu

Received January 03, 2012; Accepted January 03, 2012; Published January 05 2012

Citation: Miller VD (2012) Observations on Change. J Mass Communicat Journalism 2:e105. doi:10.4172/2165-7912.1000e105

Copyright: $\odot 2012$ Miller VD. This is an open-access article distributed under the terms of the Creative Commons Attribution License, which permits unrestricted use, distribution, and reproduction in any medium, provided the original author and source are credited. 